\title{
Barber's Forging Scientific Practices and Theories
}

This chapter weaves three arguments together and analyses how changed practices, development of theories and classifications are interlinked. Firstly, it focuses on how Barber and her colleagues at the Cape actively contributed to evolving ornithological practices. It then examines how she constructed theories of her own, before analysing, by way of example, a discussion between Barber and Trimen on the naming and classification of butterflies. In the last decade, a number of historians of science have shown that important scientific practices and theories emerged in the global South. ${ }^{1}$ This chapter aims to contribute to this on-going scholarship by arguing that the Cape Colony was not only a venue for fieldwork or a laboratory for testing Northern theories, but also a space where modern science was established in its own right.

\section{Shaping New Ornithological Practices}

Ornithology has generally been understood as a Euro-American discipline which emerged in the three decades between 1820 and $1850 .^{2}$ Nancy J. Jacobs, a historian of ornithology in Africa, for instance, has recently published a monograph containing a chapter with the telling title 'Ornithology Comes to Southern Africa, 1700-1900', in which she presents a case study of how imperial, racial and scientific status was negotiated between 'European ornithologists' and 'African vernacular birders' through scientific naming, species description and specimen collecting. ${ }^{3}$ According to

(C) The Author(s) 2019

T. Hammel, Shaping Natural History and Settler Society, Cambridge Imperial and Post-Colonial Studies Series, https://doi.org/10.1007/978-3-030-22639-8_6 
Jacobs, European naturalists introduced ornithological practices to Southern Africa where African vernacular birders had established different traditions of knowing birds. Yet ornithological practices had not evolved in the North, rather important ornithological practices developed and were advanced in the Cape in the late eighteenth and early nineteenth centuries. The following case calls for a wider reevaluation of the birth of ornithology.

Ornithology at the Cape was a collective endeavour, and Africans had a deep impact on the development of the discipline, as seen in Chap. 3. As this was 'unthinkable', it was never acknowledged in historical narratives. For the Haitian intellectual and anthropologist Michel-Rolph Trouillot, occurrences in history remain unthinkable as long as people do not have 'adequate instruments to conceptualize' them. Similarly, Bourdieu argues that events are unthinkable if humans cannot take them into account due to a 'want of ethical or political inclinations' or the 'want of instruments of thought such as problematics, concepts, methods, techniques' ${ }^{4}$ In light of the then widespread belief that European colonists and settlers were superior to Africans and that science could be theorised in the metropole alone, it remained unthinkable within the framework of Western thought that important scientific practices in ornithology, which would substantively change the discipline, could be forged at the peripheries of European colonial power with non-Europeans playing a crucial role in the process.

However, the Cape has had a large influence on the development of ornithology since the late eighteenth century. In 1781, the treasurer of the Dutch East India Company, Jacob Temminck, sent the Surinam-born French naturalist François Levaillant ${ }^{5}$ (1753-1824) to the colony to collect birds. Levaillant made three journeys through the colony over the course of the following five years: the first from Cape Town to Saldanha Bay, the second eastwards from the Cape and the third in a northerly direction beyond the Orange River and on to Namaqualand. ${ }^{6}$ During this time, the zoological collector and explorer became a naturalist and author, who pioneered a new genre in his subsequent writings, namely the compendium detailing all birds of a given region. With his Histoire Naturelle des Oiseaux d'Afrique, which was published in six volumes between 1799 and 1808, Levaillant also developed a range of new ornithological techniques. ${ }^{7} \mathrm{He}$ was among the first to use coloured plates in his descriptions and had developed colour-printing techniques that enabled him to depict bird plumage more vividly than his predecessors and contemporaries. His mounting the stuffed birds in lifelike positions with the help of arsenic soap 
allowed the illustrators to portray them in more realistic poses. His detailed descriptions of bird behaviour, his opposition to Linnaean nomenclature and his consequential use of French names were also new to ornithology.

Levaillant had barely been known or acknowledged for these innovations until the first decade of the twenty-first century. Instead, his legacy was marginalised and thoroughly discredited, primarily for a series of conspicuous errors in his text. For example, he had listed fifty species which were not to be found at the Cape or, in most cases, even in Africa. He had also detailed ten birds that were unidentifiable by other ornithologists and appeared to have come up with another ten species which were either completely fabricated or composites of different species, as argued by Carl Jakob Sundevall of the Stockholm Museum, who wrote a critical review in Swedish and Latin fifty years after Levaillant's publication. ${ }^{8}$ In sum, 20 out of 300 birds are unknown species, fabricated by a taxidermist, some are European or American birds and some are not attributed to their correct location. ${ }^{9}$

Edgar Leopold Layard, the curator of the South African Museum from 1855 to 1872 , missed no opportunity to belittle Levaillant's efforts. He argued that the taxidermist had gone so far as to have 'manufactured species' by gluing a 'false white breast' to 'the original skin' of some of his specimens. Layard also claimed that Levaillant had misclassified species, described birds from India as African and had not visited the places which he mentioned in his books in person. In fact, Layard and his successors even doubted whether Levaillant had been in South Africa at all.

Layard's attacks destroyed Levaillant's reputation, with subsequent ornithologists casting doubt on every detail of the information which he had provided. Far from being commemorated as an ornithological pioneer, Levaillant was instead remembered as a womaniser and drunk: a 'flamboyant, charismatic, ladykiller', 'drunk with success', who after 'living in an attic', 'died in poverty'. ${ }^{10}$ With Levaillant's Oiseaux d'Afrique also never having been fully translated into English, Layard long enjoyed the fruits of his counterpart's marginalisation, which stood in stark contrast to his own recognition as the founding figure of South African ornithology. ${ }^{11}$

However, despite Levaillant's scholarly shortcomings, his conceptual and technological innovations have ultimately been recognised as groundbreaking. The Dutch biologist and historian of zoology Kees Rookmaaker, an expert on the zoological exploration in Africa, was one of the first to realise the importance of Levaillant's work. In 2004, he collaborated with 
the ornithologist and conservationist Peter J. Mundy from the Department of National Parks and Wildlife Management, University of Bulawayo, Zimbabwe, the South African media scholar Ian Glenn and the British historian of knowledge Emma C. Spary, who is an expert in the history of French natural history in the eighteenth century. The result was a lavishly illustrated monograph that made Levaillant belatedly well-known and celebrated. ${ }^{12}$ His current renown, in turn, misleads many scholars who are otherwise familiar with the history of science at the Cape to overlook his earlier persistent marginalisation. ${ }^{13}$

With his encyclopaedia on the birds of Southern Africa, Levaillant initiated a new trend in the study of birds. For example, he was greatly admired by the American ornithologist and painter John James Audubon (born Jean-Jacques, 1785-1851), who would become the most acclaimed ornithologist of his day and who was particularly well-known for his colourplated volume on The Birds of America which was first published as a series in sections between 1827 and 1839. Audubon owned copies of Levaillant's books in his library and drew on them for inspiration, albeit without acknowledgement, such as when deciding to illustrate birds in life-size. ${ }^{14}$ At the Cape, Levaillant also inspired Layard who undertook what Levaillant had accomplished but for an English-speaking readership.

Layard was familiar with ornithological publications on British birds in Britain. Thomas Bewick's popular History of British Birds (1797, 1804) marked the beginning of a series of ornithological publications in Britain. ${ }^{15}$ There were at least eight multivolume projects on British birds published between 1821 and 1843. ${ }^{16}$ These were the first inexpensive illustrated ornithological volumes aimed at middle-class readers. Books and illustrations for children or lay audiences written by scientific popularisers were also greatly demanded in the first half of the nineteenth century. ${ }^{17}$ Audubon complained on a visit to London in 1835 that: 'Here they are at present [...] publishing [...] Works on the Birds of all the World [...] Cheap as dirt and more dirty than dirt. ${ }^{18}$ Layard was eager to provide a remedy for the absence of a comparable English-language compendium on South African birds.

His project, which he began in 1856, culminated in the publication of The Birds of South Africa in 1867. ${ }^{19}$ The book is organised according to the classification system developed by George Robert Gray, head of the ornithological section of the British Museum, in Genera of Birds (1840), ${ }^{20}$ the then most comprehensive list of orders, tribes, families and genera for ornithologists. The Birds of South Africa was reviewed by English banker, 
amateur ornithologist and Liberal Party politician John Henry Gurney as the 'most useful book of reference to all who desire to investigate the ornithology of that region, whilst the very valuable, though succinct, information $[\ldots]$ to all lovers of birds and of that bird-life which is equally full of interest in every quarter of the globe'. ${ }^{21}$

Much of Layard's information came from Barber, who apparently was the first woman ornithologist in South Africa. Despite his marginalisation of her, discussed in Chap. 4 , she was the first person in South Africa whom he acknowledged after his British colleagues in his non-alphabetical list of contributors and the only woman whom he quoted in his work. ${ }^{22}$ This acknowledgement made her visible, but - through taking her under his wing and subsuming her work under his-concealed her individual contribution to ornithology.

In the years after the publication of The Birds of South Africa, Barber did not only add her observations to her personal copy, but also illustrated many species out of the conviction that she could better understand the peculiarities of birds and other organisms by illustrating them. Her aquarelles were not to be merely used for illustrative purposes though; in juxtaposition, image and text augmented and supplemented one another, as detailed in Chap. 8. She thereby refined Levaillant's method and created her own personal field guide before this became a popular genre. When Layard met her on a fieldwork excursion in 1870, he found her 'interleaved and well annotated!' copy of The Birds of South Africa and was convinced that its transformation into a field guide would encourage many young people to take up ornithology. ${ }^{23}$

To prepare for her illustrations, Barber observed living birds in the wild, comparing them to her own previous sketches. While bird-watching on horseback, she ensured that she blended into the landscape, presumably by wearing clothes that matched her environment. On foot, she would have walked slowly and silently, although she may have imitated bird vocalisation. She would have concealed herself by leaning against a tree or pulling a branch down in front of her. If her position offered her a good view, she would probably have remained there for several hours. At night, she wrote a fair copy of her notes from the day in one of her notebooks that she later revised when writing her letters and papers.

She thus pioneered a new practice of illustrating birds which no longer required their killing. As discussed in Chap. 3, she was influenced by the amaXhosa who refused to kill the birds which they considered as mediators between humans and ancestors. She might have also read about 
similar advice given by the Khoekhoen and San to early European explorers such as Sparrman, Levaillant and Holub, who nevertheless all killed birds for their collections. Sparrman, for example, had followed the honig-wyzer and found his African co-workers 'too much the bird's friend to betray it'. Later, he did succeed in shooting one which caused outrage among his nine travelling companions. Levaillant recorded similar experiences. While he reported how he enjoyed killing a bird from a species which he had not seen before, he described how his African colleagues were shocked and astonished to see that he killed birds only to restore them immediately to their natural appearance. ${ }^{24}$ For her part, Barber became more and more reluctant to kill or ask for the killing of birds. There is no evidence for her killing and stuffing birds herself.

When necessary, Barber consulted museum collections and observed already-dead specimens there or borrowed stuffed specimens from colleagues. Due to her close ties with the entomologist, ornithologist and doctor Edwin Atherstone (1842-1898), her husband's cousin, she had unlimited access to his bird collection at the Albany Museum in Grahamstown. Atherstone was used to working with women at the hospitals and was particularly supportive of Barber's scientific pursuits in ornithology. He added specimens of numerous rare bird species to the Albany Museum's collections, including in 1861, when he donated thirty-nine species. He collected in a ten-kilometre-radius around Grahamstown and exhibited birds at meetings of the Albany Natural History Society (founded in 1867). From 1872 to 1890 , he seemed less scientifically active. In 1890 , he identified birds and was part of a group of naturalists who decided to revive the Albany Natural History Society. ${ }^{25}$ In 1868, Barber, for instance, borrowed two stuffed birds from him. ${ }^{26}$ She also kept birds as pets, including a vulture and a starling, thus allowing her to observe their habits closely. ${ }^{27}$

As practised by Barber, this shift in the common scientific approach to ornithology - from the killing of birds for specimens to observing them in the wild-coincided with her efforts to raise awareness for the need for regulated bird conservation. During the first half of the nineteenth century, the human-induced decline and extinction of birds was widely discussed in the English-speaking world, including at the Cape. For example, the extinct dodo, formerly a native to Mauritius, was featured in the Penny Magazine in $1833 .{ }^{28}$ In Chapters 2 and 3 of his 1865 book Alice's 
Adventures in Wonderland, Lewis Carrol portrayed the dodo as a character and thus inspired the widespread use of the simile 'as dead as a dodo'. ${ }^{29}$

While Barber had believed that nature was in balance and harmony and could protect itself, she, by the 1870s, had become aware that humans required laws and restrictions to ensure nature's protection, such as harsh punishment for over-loading ox-wagons and the introduction of restrictions on wagonloads. ${ }^{30}$ This change in perception occurred when traumatically experiencing the change in nature at the diamond fields. Upon arrival in 1871, Barber had admired Colesberg Kopje's natural beauty. ${ }^{31}$ The area changed rapidly as her watercolour of Kimberley a few years later shows. ${ }^{32}$ In 1878, Barber was convinced that humans were 'but a link in that wondrous chain which connects all earthly things' and that they should never 'imagine that all that is grand and beautiful in nature [... were solely created for the gratification of human beings' ${ }^{33}$ A year later, when leaving Kimberley, she complained that it was never noiseless: there was always dynamite blasting, machinery and the chattering in various languages. She also mentioned that there were sardine tins, broken bottles and cases that previously had contained preserved meat lying everywhere on the ground. ${ }^{34}$

Having been concerned about threats to the mockingbird, guinea fowl and partridge since 1871, ${ }^{35}$ Barber wrote 'A Plea for Insectivorous Birds' which was published in The Grabam's Town Journal and as a pamphlet in 1886 , as shown in Chap. 4 . She sent a paper that she called 'on the protection of birds' to Trimen for review. He commented on and returned it in the winter of $1885 .^{36}$

Aware of how birds were utilised to get rid of insects in other parts of the world, Barber wrote how wild birds had been protected in Ceylon since 1884, as had been humming-birds in Mauritius and the West Indies since 1885. In France and Canada, meanwhile, small birds from other parts of the world had been introduced to prevent insect pests. ${ }^{37}$ She saw these developments as examples which the Cape Colony should follow in much the same way. The movement to protect birds was transnational, and legislations influenced one another. ${ }^{38}$ Barber was especially concerned with insectivorous birds that were important for agriculture, many of which were nevertheless killed for their beautiful plumage.

Women played an important role in the development of this new ornithological approach centred on the protection of birds from humans. Early feminists, as I will show in Chap. 8, helped to revolutionise birding at a time at which the conservation, birding and female reform movements 
overlapped in ideology as well as in terms of the people who proposed these philosophies. This led to a radical transformation of the study of avian life in the late nineteenth century. As Barber had proposed in the 1870s, in 1883, the American ornithologist Florence Augusta Merriam Bailey (1863-1948) suggested going to museums to compare bird skins with those of birds which had been observed in the field. To Merriam, a robin was a 'self-respecting American citizen' and should thus be viewed 'not as a thing to be watched or even owned, but as a living, breathing citizen of the world'. ${ }^{39}$ She wrote the field guide Birds Through an Opera-Glass (1890), which has been celebrated as one of the first of its genre..$^{40}$ Although efforts to protect birds by Americans such as Merriam predominate in the historiography, ${ }^{41}$ such approaches were neither unique nor new in the late nineteenth century, nor were American ornithologists the first to develop such ideas. Barber herself had already contributed considerably to the promotion of this newly forged non-violent study of birds, a movement which had originated as a product of many people making 'multiple discover[ies]' or 'simultaneous invention[s]', for instance at the Cape, where they had primarily been inspired by African birding practices as well as the illustrated books on the birds of the region first pioneered by Levaillant. ${ }^{42}$

In this regard, Barber was ahead of her time and, although her efforts remained partly invisible in her day, her ideas have nevertheless proven influential in the discipline. Early efforts at avian conservation included two regional and local societies that aimed to protect certain species of British birds in England, while the Australian colonial parliament passed legislation to protect native birds in the late 1870s. Barber, however, was most likely not aware of these developments when she published her article in $1886 .{ }^{43}$ In Britain and the US, the movement to protect birds only gained momentum after the publication of Barber's article and pamphlet 'A Plea on Insectivorous Birds'. The Royal Society for the Protection of Birds, for instance, established in 1889, which consisted solely of women, began its work by campaigning against the plumage trade.

In 1900, a year after Barber's death, the first international environmental agreement, the Convention for the Preservation of Animals, Birds and Fish in Africa, was signed by the German, French, British, Portuguese, Spanish, Italian and Belgian colonial powers in London. This convention paid little attention to non-game animals, including birds, which were assumed not to be in danger. Its primary aim was the control of the ivory, fish skin and trophy trade for which closed seasons were proposed as the most effective measure. The agreement was never implemented, but is of lasting importance as the precedent for later legislation. 
In 1903, the first international environmental organisation, the Society for the Preservation of the Wild Fauna of the Empire (now the Fauna and Flora Preservation Society), was founded, sponsored by both hunters and naturalists. The society aimed to encourage the protection of fauna-in effect, birds and the larger mammals - in the colonies. ${ }^{44}$ The trade for exotic feathers was centred in London, with manufacturing primarily taking place in Paris and New York and peaked between 1901 and 1910. ${ }^{45}$ Thereafter, protests were organised throughout the second decade of the century by the Royal Society for the Protection of Birds, a campaign which successfully climaxed in the Plumage Bill (1920), thirty-four years after Barber had published her article. ${ }^{46}$

In the same way as bird feathers from across the Empire came to Britain, so too did knowledge about living birds and ideas for their protection arrive in the metropole from the colonial periphery. Barber was at the forefront of one such movement to protect birds and limit trading practices. Her contribution was the result of an amalgamation of her scientific observations and public activism with her influences from indigenous practices. Yet, Barber not only contributed to the birth of new scientific practices, she also had her own interpretations of what she observed.

\section{BARBER's THEORIES}

Barber's correspondence reveals that from the very beginning of her career, she did not content herself with only collecting and providing information for colleagues who were fortunate enough to have a paid scientific position in an urban or metropolitan institution. She was also not afraid to voice her opinion when she did not agree with a proposed explanation for a natural phenomenon.

On one such occasion, Barber explained her theory that birds were to a large degree responsible for the varied vegetation found on islands. This occurred in an exchange with Joseph Hooker while they were discussing the script of a lecture he had given at a meeting of the British Association for the Advancement of Science in Nottingham on 27 August 1866 and which he had sent her after publication. ${ }^{47}$ Barber interpreted receiving the text as an invitation to critique and refine his arguments and as a testament to Hooker's high regard for her. She replied to Hooker that ocean currents could not be responsible for the flora on islands in the ocean as small seeds of grasses and other plants were destroyed when immersed in water for too long. In contrast, she was certain that birds, in particular migratory 
birds, were really 'the sowers of seeds'. They, she argued, carried numerous ripe and uninjured seeds in their crops. Hooker had previously argued that they carried them in their stomachs, but Barber found this unlikely as their digestion would have damaged the seeds. ${ }^{48}$ Hooker wrote to Barber again on the matter, and she confidently replied once more that, unlike Darwin who saw currents as the main source of island vegetation, she remained convinced that birds were its main cause. ${ }^{49}$

In an article published in 1880, she claimed that locusts and locust birds kept 'each other in check, ever regulating the balance of their power' ${ }^{50}$ Barber was again ahead of her time with this theory as it took until the 1920s for the relationship between prey and predators to be scientifically defined in the Lotka-Volterra or predator-prey equations-the first-order, non-linear, differential equations are used to describe biological systems in which two species, a predator and a prey, interact. ${ }^{51}$ Sparrman and others had discussed predator-prey relations and the balance of nature, and it can be assumed that Barber had access to this earlier literature in Atherstone's library. Her interest in the topic may have been triggered by previous research, yet she considerably developed the theory and made unique observations with regard to locusts and locust birds.

She had written a first version of her paper in 1865, when she wrote to Trimen: 'Will you be so kind as to send me Mr. Darwin's articles? I am going to send him a history of that gigantic struggle for life - the locusts and the locust birds! As it is one of the most including that I know of, and quite agreeing with his reviews' ${ }^{52}$ Locust birds depended on locusts, she argued. The number of birds increased when food was plentiful, which made the number of locusts diminish in turn, but never entirely to the point of extermination. ${ }^{53}$ Locusts travel northwards into the interior of the continent followed by the predators. ${ }^{54}$ The birds then dispersed and probably died. ${ }^{55}$ Humans, meanwhile, adapted to their environment by consuming locusts when they were plentiful. ${ }^{56}$

Barber also observed Dorthesia, 'the Australian blight' near Cape Town. She called the Australian bug, Icerya purchasi, 'another interloper [...] to harrow up our African feelings'. 'There it was, with its fluffy, disagreeable looking coat, adhering to the stems of various trees and bushes in countless thousands. A soft bodied, stationary insect, affixed to one spot, apparently immoveable, yet, nevertheless, calculated to spread in all directions. ${ }^{57}$ Trimen reported that he had seen the first specimens at Claremont on an acacia obtained from the Botanic Gardens at Cape Town in 1873. It soon 
after spread and became a plague. ${ }^{58}$ It threatened the citrus crop, particularly oranges, in the Cape Colony, living on many species of trees, but particularly on Australian ornamental and fruit trees such as the acacias that were widespread. ${ }^{59}$ Barber was one of the first to observe its habits and came up with the theory that ants disseminated the plague by moving the bugs' eggs from one plant to another. At the Cape, she observed that on all the blighted trees she examined there were also ants. She suggested tarring the stems of some affected trees and testing whether the bug spread without the ants' assistance. ${ }^{60}$ Barber established her theory in analogy to the British banker, Liberal politician, archaeologist, ethnographer and biologist John Lubbock's explanation of how ants disseminated lice eggs by taking them into their nests over winter and transporting the newly hatched young to plant shoots. ${ }^{61}$ As Barber only voiced her theory in her travel account and it was not published, it fell into oblivion. Around 1885, Samuel D. Bairstow, secretary of the Eastern Province Naturalists' Society, asked the English entomologist Eleanor A. Ormerod to compile a book on the insect pests of the Cape Colony based on notes and specimens he would provide her with, which resulted in Notes and Descriptions of a Few Injurious Farm and Fruit Insects of South Africa (1889). Ormerod also published a pamphlet entitled 'Notes on the Australian bug (Icerya purchasi) in South Africa' (1887), and her article on Australian bug in the abovementioned book was published in the Agricultural Journal of the Cape Colony in 1889.62 Ormerod mentions neither Barber nor her explanation for the spread of the bug.

The fact that Barber came up with her own theories such as the above shows the degree of confidence which she placed in her scientific knowledge. She thereby also successfully demonstrated that theorising could take place in the colonial field and that women were equally capable theorisers.

\section{Butterflies Named After Xhosa Chiefs: From Visual Similarity to Visible Concealment}

Barber did not contend herself with collecting specimens, she wanted to take part in classificatory practises. The hidden story behind the classification of certain South African butterflies shows the complexities behind naming flora and fauna which require careful analysis. ${ }^{63}$ At the South African Museum, Trimen classified butterflies according to his own 
localised system. Unlike Linnaeus who classified Lepidoptera into three genera-Papilio (butterflies), Sphinx (hawkmoths) and Phalaena (all other moths)-Trimen classed them into two main groups according to their antenna shape: the Rhopalocera ('club horned' butterflies) and the Heterocera ('different horned' moths). ${ }^{64}$ Among the butterflies that Trimen classified, Pamphila Macomo, Lycsena Hintza and Lycaena Gaika are conspicuous as they were all named after Xhosa chiefs without any explanation as to why Trimen did so. ${ }^{65}$

Trimen's attitude towards Africans was ambivalent. He had grown up in England at a time when the anti-slavery movement was growing in voice and when English intellectuals were becoming increasingly aware of the moral issues arising from the imposition of colonial rule on autochthonous peoples. ${ }^{66} \mathrm{He}$ was in the philologist Wilhelm Bleek's inner circle of Cape Town-based liberals and followed Bleek and Lloyd's 'Bushmen Work' with great concern. ${ }^{67} \mathrm{He}$ thus seems to have taken an interest in indigenous South African peoples as well as their languages and cultures, and he may have aimed to contribute towards immortalising Xhosa chiefs by naming butterflies after them. ${ }^{68}$ Convinced that settler appropriation of Xhosa lands was the chief cause of the frontier conflicts, he may have viewed Maqoma, Hintsa and Ngqika in a more sympathetic light than did the settlers in Albany.

Yet, it would be a mistake to assume that Trimen was not racially prejudiced. In relation to the San, he shared in and even exaggerated the prevalent racial stereotypes of the day. A single sentence of the obituary which he wrote for Bleek is indicative of this:

Most interesting and suggestive was it to see the earnest, big-browed German, a typical example of the cultured intellect of his nation, with painstaking exactness and marvelous patience, repeating, analyzing, noting down every sound and syllable uttered by the semi-savage at his side, who - with his pigmy stature, prognathous dusky face, narrow forehead, sunken restless eyes, and harsh clicking ejaculations - might well have passed for demonimp of mediaeval story, compelled by the magic art of the alchemistphilosopher to reveal his jealously-hoarded secrets. ${ }^{69}$

While Bleek's attitude towards indigenous South African peoples has attracted much scholarly attention, ${ }^{70}$ Trimen's ideology, life and work have remained in the dark. One of the main reasons for this neglect is the unavailability of sources. ${ }^{71}$ 
In 1864, Mary Elizabeth Barber and Trimen discussed a case of butterfly naming and disagreed like never before and after. Barber had a complex emotional investment in the butterflies and their naming. She was outraged when reading these names without an explanation and could not understand Trimen. Shortly after Trimen published these names for the first time, Barber wrote to him in 1864. She reminded him of the scholarly value of Linnaeus' classifications, respectively that she agreed with Harvey 'that all barbarous names ought by all means to be avoided'. ${ }^{72}$

I am much obliged to you for the names of the Butterflies that you sent me, as for Djalala it certainly is a great curiosity a wonderful name, a name that cannot be forgotten! I am quite in love with it, [...] and I see you have been adding another to the list (I mean Macomo) how could you call a butterfly insect "child of the sun" after that son of darkness? That thing so evil, that brandy loving murderous Kafir Macomo? I like nearly all the names in your first part, ${ }^{73}$ they are pretty and fanciful but there are some terrible names in the second part $[\ldots] .^{74}$

Barber interpreted the fact that Trimen named butterflies after Xhosa chiefs as a hagiographic practice intended to immortalise them. She echoed settler tropes of 'Macomo' as an alcoholic in an attempt to demean him in Trimen's eyes and points out how misguided her correspondent had been in his choice of names. Barber's reference to the butterfly as 'child of the sun' comes from the first verse of one of the most celebrated poets during his lifetime, the English Samuel Rodgers' poem 'To the butterfly': 'Child of the sun! pursue thy rapturous flight $[\ldots]$ ]. ${ }^{75}$ Her reference to 'Macomo' as 'son of darkness' might indicate that she had heard of his Xhosa praise name-Jongumsobomvu (Watching the Sunrise), which Ngqika had given to him due to his habit of getting up before dawn ${ }^{76}$ - but that she remembered it inaccurately. This in turn would suggest that Barber was aware of the stories that circulated about the three chiefs among both settlers and the amaXhosa, yet it is rather unlikely.

Barber's experiences of the frontier conflicts radically differed from Trimen's. Trimen had arrived in Cape Town in 1859, where he spent most of his days at the Cape until his departure in 1893, and had no direct experience of the frontier conflicts between the British and the amaXhosa. Given Trimen's social ties in Cape Town, he can be expected to have been aware of the political situation, even though sources on whether he commented on social and political issues are unknown, and in his scientific work, he solely focused on the description of specimens in scientific jargon. 
Barber, who had been trying in vain to earn money through science and who, alongside her brother, had invested much time and effort to be among the first to observe and describe the three species, viewed Trimen's decision to name them after Xhosa chiefs, the stated enemies of her family, as unacceptable. She suggested he named them after "the species and the food plants, such as Cardui Hippomenus Bramca \&c., these names also divide peculiarities in the plants, and they are truly scientific'. ${ }^{77}$ Trimen did not change the names in South-African Butterflies (3 Vols., 1887-1889). ${ }^{78}$ Yet, in illustrations and descriptions, Trimen and Bowker included information on the plants that individual species frequented and as caterpillars fed upon. As Barber only complained once about Trimen's decision, it can be assumed that he convincingly explained to her his reasons for doing so.

The most plausible explanation for Trimen's naming the three butterflies after the three Xhosa chiefs is that the wings resembled the chiefs' garment patterns and skin colour. ${ }^{79}$ Pamphila Macomo was brown with quadrate, ocherous-yellow spots and blackish dots, Lycsena Hintza had hind-marginal blackish edgings and blackish spots and Lycaena Gaika was pale-blue with brownish-grey borders of variable width on hind-margins and blackish spots. ${ }^{80} \mathrm{~A}$ comparison of drawn portraits of the two chiefs that were well-known among settlers at the time with photographs of the butterflies illustrates the resemblance between wing and garment patterns.

Ngqika typically wore the traditional royal dress of leopard skin garments as a sign of his high rank and was favourably described by British and German travellers who had personally met him. ${ }^{81}$ These descriptions of a physically handsome and attractive man might also have influenced Trimen's decision to name a butterfly after Ngqika. ${ }^{82}$ An additional reason was that Lycaena gaika, according to Trimen's description, had longer wings, a 'more delicate texture', a more slender and elongated abdomen than most other species of the genus. ${ }^{83}$ Besides visual similarity, the three butterflies' habitat (Kaffraria and British Kaffraria) influenced Trimen to name them after Xhosa chiefs. What may seem to be an appreciation of otherness or a celebration of the other, however, is potentially never far removed from the denigration, annihilation or silencing of difference.

Trimen also named the three soft and fragile animals with short life spans after the three Xhosa chiefs to celebrate European military success over the amaXhosa. The butterflies were named at a time when the British felt secure in their belief that they had defeated the Xhosa nation represented by the three chiefs. The naming thus suggests a celebration of settler success, power and conquest. To understand what Trimen may have 
known about the three chiefs, I briefly reconstruct key moments in Xhosa relations with the British from a settler perspective (until 1864) to demonstrate that the process of butterfly naming was a more complex act than a simple commemoration of the three Xhosa heroes-Gaika, Hintza and Macomo to use the names used by the colonialists.

Lycaena Gaika was named after Gaika (c. 1779-1829). After defeating his ward and uncle Ndlambe in 1795, the British called him Paramount Chief. He expanded his control and started collaborating with the British, whom he saw as potential allies against Ndlambe, by returning stolen cattle and deserters to the Cape. Gaika, who realised that he was so alienated from his own people that he could only rely on the Colony for protection, sought to gain as many benefits from this new alliance as possible, while blaming Ndlambe for thefts that his own followers had committed and from which he had himself profited. At the great battle of Amalinde in October 1818 - 'the greatest and most terrible battle' the amaXhosa ever fought among themselves-Gaika lost. ${ }^{84} \mathrm{He}$ is said to have frequented the colonial barracks, to have felt betrayed, but dependent on the colonial authorities. Having morally capitulated and having spent all the money he had on brandy until his body was ultimately ravaged by liquor and tuberculosis, he died in $1829 .{ }^{85}$

Lycsena Hintza was named after Hintza (1789-1835) who had been the fourth paramount chief of the Gcaleka, a subgroup of the Xhosa nation, since $1820 .{ }^{86}$ The British accused him of instigating the 1834 Xhosa invasion of the Cape Colony and in 1835 took him prisoner. For his release, they demanded 5000 heads of cattle and 500 horses as 'war damages' to replace those which had supposedly been stolen from settlers in and around Grahamstown. ${ }^{87}$ Forced to accompany Colonel Harry Smith on a mission to raid Gcaleka stock on 12 May 1835, Hintza allegedly tried to escape and was pursued by Smith and George Southey, who shot him in the legs. Hintza fell from his horse, ran with bleeding legs to a stream and fired an assegai that missed Southey. Southey shot him in his head. His body was then mutilated on the banks of the Nqabara River, with his ear (or ears) said to have been cut off and sent to Grahamstown, as a war trophy, and his head reportedly severed and dispatched to Britain. ${ }^{88}$

Pamphila Macomo was named after chief Macomo (1798-1873), the first son born to Chief Gaika's Right-hand House, the second wife, and thus not his heir. ${ }^{89}$ Yet when his father died, Macomo became regent and emerged as the most significant of the Western Xhosa chiefs. His brother Sandile (c. 1820-1878) became chief of the amaNgqika in 1842, and 
Macomo was disempowered and introduced to strong liquor at the military canteen in Fort Beaufort. The end of the Seventh Cape-Xhosa War left the amaNgqika negotiating with the new Governor, Sir George Cathcart, as Macomo's guerrilla bands were starved and exhausted. The British banished the amaNgqika from the Amathole Mountains and squeezed them into a cramped and impoverished reserve on the Western bank of the Kei River. Following the starvation after the Xhosa CattleKilling of 1856-1857, Macomo was arrested in 1858 and sentenced to death, which was commuted to twenty years' imprisonment and hard labour on Robben Island. Thus, removed from his own territory to make way for a Khoekhoe settlement, Macomo had, from the perspective of the British settlers, been successfully humiliated, exiled, impoverished, defeated and imprisoned. In short, the majority of contemporary colonial sources generally described him as a 'drunken troublemaker' 90 and cattle thief who masterminded an unprovoked attack on the colony in 1834 and eventually led his subjects into the irrational Cattle Killing catastrophe of 1856-1857. ${ }^{91}$

Naming the butterflies after these unsuccessful insurgents allowed the British and settlers celebrate themselves. This is all the more realistic given that the type specimens after which Trimen named the butterflies had been collected by the British naturalist William Stewart Mitchell D'Urban (1836-1934), Sir Benjamin D'Urban's grandson, who had spent much of his early life with his grandfather at Wynberg. ${ }^{92}$ Benjamin D'Urban attacked the amaXhosa in the Sixth Cape-Xhosa War, let Hintza be murdered and annexed the territory between the Keiskamma and Kei Rivers which he called Queen Adelaide Province. Thereby, for the first time in African history, Africans stood under the direct rule of the British. ${ }^{93}$ It has been argued that Hintza was actually murdered by D'Urban. ${ }^{94}$ As this murder was harshly condemned both at the Cape and in Britain, Albany settlers sought to demonise Hintza as 'an inveterate liar' and for 'having plotted against the colony before the war'. ${ }^{95}$ D'Urban was pleased with the news of Hintza's death, ${ }^{96}$ but received orders from London to organise a court inquiry into the alleged murder in August 1836. This resulted in no one being held responsible but in criticism of the corpse's mutilation. However, activism on the part of British and Cape humanitarians compelled the British colonial secretary Lord Glenelg to intervene by returning the conquered Xhosa land between Fish River and Kei River as well as to establish treaty relations with Xhosa chiefs. The 1836 commission's distorted version of what had happened resulted in 'the growing malig- 
nant image of blacks' in the colony. ${ }^{97}$ This became part of what came to be considered the Cape's 'definitive history', as propagated in George Cory's The Rise of South Africa (1921-1932) in which Hintza is portrayed to have had 'all the vices of the savage, cruelty, treachery, avarice, and the deepest cunning [...] Hintza got no more than the reward for his perfidy'. ${ }^{98}$

The third possible explanation is that Trimen was aware that the chiefs were discussed in starkly contrasting ways by the amaXhosa and decided to make Ngqika, Hintsa and Maqoma visible in order to conceal the importance they played in contemporary Xhosa society. ${ }^{99}$ For his part, Trimen would have been aware that the amaXhosa celebrated the three chiefs as key figures in African resistance for withstanding the British pressure for much longer and far more successfully than the colonial interpretations allowed to believe.

Naming butterflies after Xhosa chiefs mirrors a similar practice in nineteenth-century settler colonial art and the humanities, namely the representation of indigenous peoples. The German philologist Wilhelm Bleek recorded tales and songs to analyse the sounds of dying languages; George William Stow recorded rock art as relics of the almost extinct Bushmen and artists such as Frederick Timpson I'Ons painted souvenir portraits of the autochthonous population such as in his South African Portraits (1836). ${ }^{100}$ It was generally believed that these groups had to be portrayed and recorded before they inevitably died out, unable to compete with the advance of white civilisation. Similar to feel-good stories of how settlers helped Africans to survive, which were passed down over several generations even while the deaths and destruction caused in the selfsame colonial process were silenced, art works and scientific names served as mascots and mementos of settler survival. Yet, there is a difference between the two: paintings (or busts and sculptures) were mostly created when the indigenous subjects were still alive, ${ }^{101}$ while Trimen posthumously named butterflies after the three chiefs.

In analogy to what Rebekka Habermas has called 'eloquent silence', ${ }^{102}$ I see these works of art and Trimen's naming practice as visible concealing. ${ }^{103}$ Eloquent silence, according to Habermas, is the process by which a scandal, for instance, serves to hide more than it exposes. ${ }^{104}$ In the case discussed at length, I focused on the presence of the absent-the names and faces of three Xhosa chiefs who, according to the British, had been killed or defeated in the colonial process. In doing so, I was interested in how the mechanism of heroising (as opposed to scandalising) also contributed to the process of silencing through a corresponding technique which 
I call visible concealing. While Xhosa chiefs became visible in butterfly names, their life stories and importance to the amaXhosa as well as the reasons for such naming were concealed.

In the end, Barber had little influence on Trimen's classification and naming of newly discovered species of Lepidoptera. However, their discussion provides insight into how racial ideologies and lived war experiences influenced naming practices which were far less objective and more frequently unrelated to an animal's appearance or behaviour than generally assumed. The discussion between Barber and Trimen also hints at tensions between radical eastern Cape settlers and Cape Town liberals. ${ }^{105}$ The contextualisation of Trimen has highlighted ambiguities in the worldviews of liberals in Cape Town as well as how ideology had an impact on naming. It also shows how the butterflies' habitat and context played a much stronger role when being named in near colonial proximity rather than in the metropole.

While Barber had described botany as a 'sovereign remedy' 106 in the Cape-Xhosa Wars, naming had a similar function to help the British cope with the horrors of war. As such, the naming of the three butterflies can be read as one coping strategy among others for the British desperate to overcome the fear of war and loss. At the same time, the heroising of chiefs - who the amaXhosa celebrate as freedom fighters today-by naming butterflies after them allowed colonial naturalists to conceal the true nature of indigenous-settler relations and the Xhosa interpretation of events by conversely appropriating their identities and, upon a first glance, paradoxically lionising them.

Barber's position within natural history was complex. As she contributed to various disciplines, she had intersecting roles that contradicted each other from time to time. Barber occupied a space in between European travellers and Africans, women and men scientists, the metropole and the periphery, wealth and poverty. Her economic, cultural and social capital varied according to the context of her research, but she was never entirely silenced. This is evident in Chaps. 4, 5 and 6, which present the complexity of her marginalisation and explore how she dealt with the highs of being published in renowned scientific journals and praised for providing corroborative evidence for evolutionary theory alongside the lows of being ignored, neglected or plagiarised.

The increasing South Africanisation of science aided and abetted these developments. In 1866, the botanists Peter MacOwan and Harry Bolus had founded the South African Botanical Exchange Society, an endeavour which aimed to send duplicates collected by amateur naturalists to over- 
seas herbaria and thereby raise worldwide interest in South African flora. ${ }^{107}$ In 1878, Barber was 'quite proud' that Trimen praised her paper 'On Colour', ${ }^{108}$ as she coveted his approval more than that of Darwin or Hooker. ${ }^{109}$ Barber, however, was convinced that Cape naturalists were already equal to their colleagues in England, if not superior, and wanted to promote this view. She predicted that South Africa 'will eventually prove to be one of the greatest and wealthiest countrys [sic!] of the world. With a flora second to none.' ${ }^{110}$ After the country's unification in 1910, the botanist Alice Marguerite Pegler (1861-1929), a teacher in Kentani who had collaborated with MacOwan, Bolus, Henry Harold Welch Pearson, Selmar Schonland, Illtyd Buller Pole-Evans, and others and who would become the first woman associate member of the Linnean Society of London in 1912, wrote in a letter to Pearson that she had sent her fungi specimens to experts in South Africa, rather than to those at the Royal Botanic Gardens Kew, as she firmly believed that South African, and not British, botanists should do the work on South African flora. ${ }^{11}$ This was indicative of an increasingly prevalent and self-confident national identity in science as South African botanists asserted their independence from British institutions and began to send specimens to experts in their own country rather than abroad. To what extent this 'South Africanisation' of science occurred during Barber's lifetime and how racial ideology shaped this process is discussed in more detail in the following chapter.

\section{Notes}

1. See for example (Raj 2007); (McCalman 2010); (Sivasundaram 2013).

2. (Farber 1982, 100).

3. See (Jacobs 2016, 78-100).

4. (Trouillot 1995, 82).

5. Also referred to as Le Vaillant.

6. See (Levaillant 1790a, b, 1795, 1796).

7. (Levaillant 1799a, b, 1802, 1805, 1806, 1808).

8. (Sundevall 1865).

9. (Jacobs 2016, 83).

10. (Layard 1867, 12, 15-16, 17, 20, 21, 22, 29, 36, 42, 49, 51, 139); (Walters 2003, 83-86).

11. (Hockey et al. 2005, 10).

12. (Rookmaaker et al. 2004); Also see (Rookmaaker 1989, 177-271); (Huigen 2009, 119-145); (Glenn 2009, 93-94). 
13. Patrick Harries, as one among many of his colleagues, for instance, assumed that he had always been well known. Jacobs does not mention his marginalisation; see for example (Jacobs 2016, 76, 82-83, 86-87, 96, $99,107,244)$. For a recent publication which celebrates Levaillant, see (Siegfried 2016).

14. (Partridge 1996, particularly 297).

15. See for example in (Brontë 1996, chapter 1, 20).

16. Prideaux John Selby's Illustrations of British Ornithology (1821-1834), Henry Leonard Meyer's Illustrations of British Birds (1835-1841), Thomas Campbell Eyton's Rarer British Birds (1836) a supplement to the much-loved Thomas Bewick's History of British Birds (1797, 1804), William Yarrell's (1837-1843) and William Macgillvray's (1837-1852) History of British Birds, William Jardine's Illustrations of Ornithology (1825-43), and William Swainson's The Naturalist's Library $(1833-43)$.

17. Jane Loudon, Reverend F. O. Morris, C. A. Johns, J. G. Wood were among the most well-known of these.

18. Audubon to John Bachman, 20 April 1835, in (Irmscher 1999, 832); also quoted in (Smith 2006, 92 ).

19. I met and corresponded with Dr. Gerald Klinghardt, Curator: Anthropology, Iziko Museums of South Africa, Cape Town, in 2011 and 2014, looked for sources at the Natural History Museum in London and traced his autobiography to the Manuscripts, Rare Books and Special Collections department of the McGill University Library in Montreal. However, none of his correspondence could be found.

20. (Gray 1840).

21. (Gurney 1868, 135).

22. (Layard 1867, vi). See for example (Layard 1869, 74, 77, 365, 366, 370, 371, 373-374); (Bowdler Sharpe 1875, 150, 782).

23. Layard to Richard Owen, Natural History Museum, London (NHM), Owen Correspondence, Vol. 17, Letter 248, Cape Town, 15 April 1870, underlined in original.

24. (A. Sparrman 1776, 2:190-191); (D. A. Sparrman 1777, 45); (Levaillant 1796, 107); (Jacobs 2016, 99).

25. RES, Trimen Correspondence, Box 18, Letter 108, Kimberley, 2 September 1878; Bertram Egerton Bowker, Reminiscences, HM, SM 57(b), 3; http://www.s2a3.org.za/bio/Biograph_final.php?serial=100, date accessed 12 February 2016.

26. M. E. Barber to Amenia Barber in England, Highlands, 16 November 1868, Late Gareth Mitford-Barberton's Private Family Archive, Serial No 015 .

27. Barber, Wanderings, MS 10560 (a), Vol. 1, 19-20, 35-37. 
28. (Broderip 1833).

29. By the 1880s, the dodo had become an 'extinction icon' see (Cheke and Turvey 2008).

30. Mary E. Barber, Wanderings, Vol. 1, MS 10560 (a) 41-42. See for example (Hammel 2016, 131).

31. Barber painted the Colesberg Kopje or New Rush, 1871, a few months before it was recognised as being diamondiferous. See (Schonland 1904, 100); Art Store, History Museum, Albany Museum Complex, Picture 1.

32. 'General view of Kimberley in the "early days." A town of tents.' (Schonland 1904, 100). Art Store, History Museum, Albany Museum Complex, Picture 2.

33. (Barber 1878, 27).

34. Barber, Wanderings, Vol. 1, MS 10560 (a), 4.

35. (Barber 1871, 332).

36. RES, Trimen Correspondence, Letter 123, Grahamstown, 24 April 1885; Letter 124, Grahamstown, 26 July 1885.

37. Barber, "A Plea for Insectivorous Birds", HM, SM 5501 (46), 5.

38. In another context, William Beinart has shown how the Natal forest code, for instance, had drawn on similar legislation in Mauritius from the eighteenth century (Beinart 1989, 147).

39. (Saxena 2015).

40. (Merriam 1890).

41. See for example (Forbes and Jermier 2002); (Merchant 1984, 2016). An exception is (Bonhomme 2007).

42. Jane Carruthers argues that Le Vaillant was not a scientist, as he did not use Linnean nomenclature and sees Dr Andrew Smith as South Africa's pioneering ornithologist (Carruthers 2004, 93). See (Merton 1963, 1973).

43. The East Riding Association for the Protection of Sea Birds was founded in 1867 and the Association for the Protection of British Birds in 1870, see (McCormick 1992, 15); (White 2013, 454). With the exception of the earlier 'An Act for the Preservation of Game and Protection of Birds in the District of Columbia' (1879) http://memory.loc.gov/cgi-bin/query/ D?consrvbib:16:./temp/ ammem_xhlk::, date accessed 4 May 2014.

44. (McCormick 1992, 18).

45. (Hornaday 1913, 145); (Doughty 1975, 29).

46. (Patchett 2011).

47. KLAA, Director's Correspondence, Vol. 189, Letter 115, Highlands, 9 May 1867. See (Hooker 1866a, b, 1867a, b). She might also have read and referred to an earlier work: (Hooker 1847).

48. KLAA, Director's Correspondence, Vol. 189, Letter 114, Barber to Hooker, Highlands, 6 May 1867. 
49. KLAA, Director's Correspondence, Vol. 189, Letter 115, no date, underlined in original.

50. (Barber 1880, 195).

51. See for example (Lotka 1910, 1920, 1925); (Volterra 1926).

52. RES, Trimen Correspondence, Box 17, Letter 40, Highlands, 5 January 1865.

53. (Barber 1880, 195).

54. (Barber 1880, 218).

55. No evidence for this part of her hypothesis has been found, as historian and ecologist Clive Spinage has argued in (Spinage 2012, 521).

56. (Barber 1880, 202-203, 204-205).

57. Barber, Wanderings, Vol. 2, MS 10560 (b), 53.

58. "Report of the Commission appointed by his Excellency the Governor to inquire into and report upon the means of exterminating the insect of the family Coccidae, commonly known as the Australian

Bug" published at Cape Town, 1877, and from the letter of Roland Trimen, dated 5 February 1877 and published by the Government Secretary of Cape Colony as "Government Notice No. 113, 1877".

59. See (Wallace 1896, 10, 94, 197-198).

60. Barber, Wanderings, Vol. 2, MS 10560 (b), 54-55.

61. Barber, Wanderings, Vol. 2, MS 10560 (b), 53. See for example (Lubbock $1877 \mathrm{a}, \mathrm{b}, 1880)$.

62. (Ormerod 1889).

63. Scholarly debate has hitherto focused on linguistic imperialism which refers to the devaluation of both vernacular names and insights. The discussion centred on whether the Linnaean systematics shared in the underlying logic of European expansion and colonisation. Some have argued that Linnaean binominal nomenclature included many more vernacular names than initially thought and that the nomenclature system was created to mediate between cultures rather than allow one to benefit at the expense of others. See for example (Cook 2010, 128); (Cooper 2007, 166-172); (Müller-Wille 2005, 48). Yet, like American historian of science Londa Schiebinger, I am convinced that however inclusive of vernacular names a European naturalist may have been, non-European plants were inevitably subsumed into a European classificatory logic (Schiebinger 2007, 105).

64. (Cohen 2002, 206). Today, entomologists distinguish four suborders Zeugloptera (mandibulate archaic moths, considered the most primitive extant lineage of Lepidoptera), Aglossata (kauri moths), Heterobathmiina (primitive, diurnal, metallic moths, confined to southern South America) and Glossata (all butterflies and moths that have a coilable proboscis.). 
65. See for example (Trimen 1862, 403). Trimen was not the first naturalist to name animals after African people. Levaillant had been in close contact with Khoekhoen and had two friends after whom he named Apaloderma narina (Narina trogon) and Chrysococcyx klaas (Klaas's cuckoo) in Oiseaux d'Afrique as an acknowledgement for their assistance. The names of 13 out of 300 species included in Levaillant's book had their roots in Southern African vernacular languages, especially in Cape Dutch, the pidgin which the Khoekhoen spoke at the time. Likewise, there were earlier examples of animals named after African chiefs. Sir Andrew Smith of the South African Museum in Cape Town, who led the 'Expedition for Exploring Central Africa' through Tswana territory in what is now the province of North West in South Africa from 1834 to 1836, recorded seventeen bird names' origination from Sotho-Tswana languages. However, he neither translated these nor disclosed their origins. For example, Smith named the white-browed sparrow-weaver as Procepasser mabali without any explanation. Jacobs has shown that Tswana speakers employed the term mogale to describe a brave or heroic individual and that Smith's mahali is based on mogale. She has not made a connection between mogale and the name of the powerful chief Mogale wa Mogale of the Po chiefdom of the Batswana, a territory which stretched from Magalisberg to Northcliff Ridge, the Vaal River and present-day Hartbeespoort Dam. He is believed to have ruled over a kingdom of miners and traders of gold, which was broken up by Zulu king Shaka, Mzilikazi and their followers, before the Voortrekkers invaded and took over land in the area of today's Mogale City. Mogale wa Mogale is recognised as one of the first freedom fighters in South Africa. Whether Smith was ignorant of these origins or deliberately chose to name the bird after Chief Mogale wa Mogale to celebrate him or European conquest of his land remains unclear. Trimen's and Smith's motives differed from Levaillant's recognising his Khoekhoe friends (Jacobs 2016, 82-83, 85, 87, 89, 94); (Hilton-Barber and Berger 2004, 41).

66. As detailed by the British Parliamentary Select Committee report on Aborigines in 1836. See (The Aborigines Protection Society 1837).

67. (Bank 2006, 66, 317).

68. See for example (Bennun 2004, 8); (Skotnes 2007, 272).

69. This obituary was first published as: R. Trimen, "Obituary of WHI Bleek", Cape Argus and republished as (T [Trimen] 1875). According to Bank, this sentence 'has rightly attracted censure for its racist contrast' between Bleek and the San informants, 'a view scarcely in keeping with Bleek's own research ethic'. (Bank 2006, 257). Dubow, however, has stressed Bleek's own ambiguous attitude towards the San (Dubow 2006, 110). 
70. See for example (Bank 2000); for a discussion of different approaches to the Bleek-Lloyd Archive, see (Rassool 2006).

71. Therefore, much of this section remains speculative. Yet as Andrew Bank has shown, historians can elucidate much about scientific practices in nineteenth-century South Africa by conjecturing. See for example (Bank 2006; Bank and Bank 2013).

72. RES, Trimen Correspondence, Box 17, Letter 39, Highlands, 6 September 1864.

73. See (Trimen 1887a).

74. RES, Trimen Correspondence, Box 17, Letter 39, Highlands, 6 September 1864, underlined in original.

75. (Mavor 1823, 324).

76. See (Stapleton 1993, 325).

77. RES, Trimen Correspondence, Box 17, Letter 39, Highlands, 6 September 1864, underlined in original.

78. See “Lycaena Gaika, Trimen”, (Trimen 1887b, 2:50-52); “Lycaena Hintza, Trimen”, in (Trimen 1887b, 2:79-80); “Thymelicus Macomo, (Trimen)", (Trimen 1889, 3:302-303).

79. See for example (Trimen 1862, 1864).

80. (Trimen 1864, 177, 403, 1866, 2:50, 243, n. 144, 2:297-298, 1887b, 2:79). Other interesting butterfly names are: Nisoniades Djaelaelae, N. Mokeezi and N. Kobela, see: (Trimen 1866, 2:310-312), Nisoniades djaelaelae is now known as The Small Marbled Elf (Eretis umbra), N. Mokeezi as The Large Sprite, Large Flat or Christmas Forester (Celaenorrhinus mokeezi) and N. kobela as The Mrs. Raven Flat or Mrs. Raven Skipper (Calleagris kobela).

81. Sketch of King Hintsa aka Khawuta, see for example (Legassick 2010, between pages 72 and 73), original: CL, APN252075. For a photograph of Zintha hintza, see http://www.lolldaiga.com/butterfly-list/ accessed 2 December 2018. André Coetzer, member of The Lepidopterists' Society of Africa, provided me with his photographs which I used in my $\mathrm{PhD}$ thesis. John Barrow, for instance, described him in 1797 as 'the adored object of his subjects; the name of Gaika was in every mouth, and it was seldom pronounced without symptoms of joy'. And Hinrich Lichtenstein (1780-1857), who met Ngqika in 1803, wrote: 'It is not hazarding too much to say that among the savages all over the globe a handsomer man could scarcely be found. Nay, one might go farther, and say that among the sovereigns of the cultivated nations it would perhaps be difficult to find so many qualities united, worthy of their dignity.' (Barrow et al. 1806, 151); (Lichtenstein 1812, 320). 
82. An engraving of the youthful Ngqika, the chief of the Rharhabe Xhosa, 1813, an impressionistic contemporary sketch, can be seen in (Mostert 1992, n.p. between 320 and 321); the original is at the Cape Archives. André Coetzer provided me with a photograph of The Gaika Blue or Tiny Grass Blue (Zizula hylax) he took in 2009, and similar photographs can be found online.

83. Lycaena gaika in (Trimen 1862, 403-404).

84. (Mostert 1992, 466).

85. (Peires 1979).

86. See for example (Crais 1992, 115).

87. (Mostert 1992, 366); (Lalu 2009, 34); (Peires 1989, 84-85).

88. (Lalu 2009, 31, 34).

89. See for example (Peires 1975).

90. In 'the War of the Axe' (1846-1847) 'Colonial sources attempted to discredit Maqoma by claiming that he capitulated early because of alcohol-induced insanity', (Stapleton 1993, 326).

91. The teenage prophetess Nongqawuse initiated a millennialist movement that culminated in the Xhosa cattle-killing crisis of 1856-1857. She called on thousands of amaXhosa to slaughter their cattle and cast their seeds to the wind, a disastrous appeal which resulted in the death of 25,000 people from mass starvation and the loss of much of their land as well as the migration of thousands of amaXhosa into the Cape Colony as labourers (Stapleton 1993, 321); Saunders, "Maqoma (1798-1873)", in (Stapleton 2016, 455). For more on Nongqawuse, see (Bradford 1996, 2007, 2008; Bradford and Qotole 2008).

92. Governor D'Urban is said to have been more Whig than Tory in disposition and liberal-minded when he arrived in Cape Town on 10 January 1834. His outlook was humanitarian, and his main aim was to treat Africans better and to enable slave emancipation, which he succeeded in accomplishing on 1 December 1834. While D'Urban only allowed shooting at the frontier in self-defence, he was unaware of the gravity of the conflict (Mostert 1992, 635, 639-640, 645, 650, 728).

93. "Benjamin D'Urban" in Encyclopaedia Britannica: https://www.britannica.com/biography/Benjamin-DUrban, last updated 8 April 2009, date accessed 21 November 2016.

94. See for example in the novel (Mda 2000, 86).

95. (Watson 2012, 109); Timothy J. Stapleton, "Hintsa (c. 1790-1835)", in (Stapleton 2016, 349).

96. (Mostert 1992, 727, 728).

97. (Watson 2012, 110).

98. (Watson 2012, 116). 
99. Given the absence of contemporary sources in isiXhosa and of research literature by Xhosa historians, we need to reconstruct how the amaXhosa experienced the three chiefs' lives differently through literature that has taken Xhosa oral histories into account. Interpretations and narrations changed over time, but the core and the main difference to settler interpretations have been fixed since the events' occurrences. See for example (Peires 1981, 1989); (Wells 2012); (Stapleton 1993, 1994, 77, 111, 113, 118, 121-122, 127, 131, 138-140, 223-224); (Peires 1981); Saunders, "Maqoma" in (Stapleton 2016, 454); (Legassick 2010, 23); (Lalu 2009, $28,74)$. The Xhosa proverb omasiza mbulala, 'they who came to help came to kill', emerged from the Xhosa nation's experience with the British while under Ngqika. Quoted in (Peires 1981, 79). The ruling Xhosa king has awarded the King Hintsa Bravery Award since 1999.

100. Two early pieces of Australian sculpture, the British artist Benjamin Law's busts of Woureddy (1835) and Trucaninny (1836) — two of the most celebrated Tasmanian Aboriginal individuals of the 1830s-have attracted considerable attention in this regard. These were recognised as ethnographic records depicting Aborigines 'in their primitive state', not as pieces of art by contemporary artists (Bonyhady 2010). Mary Mackay, for example, described Woureddy's bust as depicting a 'hunter, warrior and man-in-command, a Greek hero in kangaroo skin', in (Thomas et al. 1988, 93). Truganini (*1812), the best-known Tasmanian Aboriginal woman of the colonial era, was from the Nuenonne group, Bruny Island, and spent twenty years in detention on Flinders Island and another seventeen years in the Oyster Cove camp, south of Hobart. Hundred years after her death, the Palawa people, modern Aboriginal Tasmanians, cremated her remains and scattered her ashes in the D'Entrecasteaux Channel, close to her birthplace and homeland (Florek 2016a, b).

101. An exception is I'Ons by now famous depiction of Makhanda, for more on that see (Wells 2012, 50).

102. My translation for 'beredtes Schweigen'.

103. In German, I would call it 'ersichtlich gemachtes Verhüllen'.

104. (Habermas 2016, 17).

105. I do not go into further detail here as Andrew Bank has already done so in (Bank 1995).

106. Letter to Harvey in Flora Capensis, quoted in (Mitford-Barberton 1934, $85)$.

107. (Gunn and Codd 1981, 183).

108. (Barber 1878).

109. RES, Trimen Correspondence, Box 18, Letter 105, Kimberley, 11 April 1878 . 
110. Barber to Joseph D. Hooker, KLAA, Director's Correspondence, Vol. 189, Letter 134, Johannesburg, 4 March 1888.

111. Alice M. Pegler to Dr. Pearson, Kentani, 19 June 1912, Manuscripts and Archive Division, UCT, BC 234.

\section{REFERENCES}

Bank, Andrew. 1995. Liberals and Their Enemies: Racial Ideology at the Cape of Good Hope, 1820 to 1850. Cambridge: Cambridge University Press.

- 2000. Evolution and Racial Theory: The Hidden Side of Wilhelm Bleek. South African Historical Journal 43: 163-178.

- 2006. Bushmen in a Victorian World: The Remarkable Story of the BleekLloyd Collection of Bushman Folklore. Cape Town: Double Storey Press.

Bank, Andrew, and Leslie Bank. 2013. Inside African Anthropology: Monica Wilson and Her Interpreters. Cambridge: Cambridge University Press.

Barber, M.E. 1871. Night at Du Toit's Pan; Notes form a Journal. Cape Monthly Magazine, 331-333.

- 1878. On the Peculiar Colours of Animals in Relation to Habits of Life. Transactions of the South African Philosophical Society 4: 27-45.

- 1880. Locusts and Locust Birds. Transactions of the South African Philosophical Society 1: 193-218.

Barrow, John, Samuel Daniell, and Thomas Medland. 1806. Travels into the Interior of Southern Africa: In Which are Described the Character and the Condition of the Dutch Colonists of the Cape of Good Hope, and of the Several Tribes of Natives Beyond Its Limits: The Natural History of Such Subjects as Occurred in the Animal, Mineral and Vegetable Kingdoms; and the Geography of the Southern Extremity of Africa: Comprehending Also a Topographical and Statistical Sketch of Cape Colony; With an Inquiry into Its Importance as a Naval and Military Station, as a Commercial Emporium; as a Territorial Possession. London: Printed for T. Cadell and W. Davis. doi:https:// doi.org/10.5962/bhl.title.101281.

Beinart, William. 1989. Introduction: The Politics of Colonial Conservation. Journal of Southern African Studies 15: 143-162.

Bennun, Neil. 2004. The Broken String: The Last Words of an Extinct People. London: Viking.

Bonhomme, Brian. 2007. For the 'Preservation of Friends' and the 'Destruction of Enemies': Studying and Protecting Birds in Late Imperial Russia. Environment and History 13: 71-100.

Bonyhady, Tim. 2010. Benjamin Law. Canberra: National Gallery of Australia. Bowdler Sharpe, Robert. 1875. The Birds of South Africa, New Ed., Thoroughly Revised and Augmented. London: Bernhard Quarith. 
Bradford, Helen. 1996. Women, Gender and Colonialism: Rethinking the History of the British Cape Colony and Its Frontier Zones, c. 1806-1870. The Journal of African History 37: 360-368.

- 2007. Not a Nongqawuse Story: An Anti-Heroine in Historical Perspective. In Women in South African History: Basusiimbokodo, Bawel'imilambo/They Remove Boulders and Cross Rivers, ed. Nomboniso Gasa, 43-89. Cape Town: HSRC Press.

- 2008. Akukho Ntaka Inokubhabha Ngephiko Elinye (No Bird Can Fly on One Wing): The 'Cattle-Killing Delusion' and Black Intellectuals, c. 1840-1910. African Studies 67: 209-232.

Bradford, Helen, and Msokoli Qotole. 2008. Ingxoxo enkulu ngoNongqawuse (A Great Debate About Nongqawuse's Era). Kronos 34: 66-105.

Broderip, W.J. 1833. Dodo. Penny Magazine of the Society for the Diffusion of Useful Knowledge 75: 209-211.

Brontë, Charlotte. 1996. In Jane Eyre, ed. Beth Newman. Boston: St Martin's.

Carruthers, Jane. 2004. Our Beautiful and Useful Allies': Aspects of Ornithology in Twentieth Century South Africa. Historia 49: 89-109.

Cheke, A.S., and S.T. Turvey. 2008. Dead as a Dodo: The Fortuitous Rise to Fame of an Extinction Icon. Historical Biology 20: 149-163.

Cohen, Alan. 2002. Roland Trimen and the Merope Harem. Notes and Records: The Royal Society Journal of the History of Science 56: 205-218.

Cook, Alexandra. 2010. Linnaeus and Chinese Plants: A Test of the Linguistic Imperialism Thesis. Notes \& Records of the Royal Society 64: 121-138.

Cooper, Alix. 2007. Inventing the Indigenous: Local Knowledge and Natural History in Early Modern Europe. Cambridge: Cambridge University Press.

Crais, Clifton C. 1992. White Supremacy and Black Resistance in Pre-Industrial South Africa: The Making of the Colonial Order in the Eastern Cape, 1770-1865. Cambridge: Cambridge University Press.

Doughty, Robin W. 1975. Feather Fashions and Bird Preservation: A Study in Nature Protection. Berkeley/Los Angeles: University of California Press.

Dubow, Saul. 2006. A Commonwealth of Knowledge: Science, Sensibility and White South Africa 1820-2000. Oxford: Oxford University Press.

Farber, Paul. 1982. The Emergence of Ornithology as a Scientific Discipline. Dordrecht: Reidel.

Florek, Stan. 2016a. Truganini (1812?-1876). Australian Museum. http://australianmuseum.net.au/blogpost/science/our-global-neighbours-remembering-truganini (20 July 2016).

- 2016b. Our Global Neighbours: Remembering Truganini. Australian Museum. http://australianmuseum.net.au/truganini-1812-1876 July 2016)

Forbes, Linda C., and John Jermier. 2002. The Institutionalization of Bird Protection: Mabel Osgood Wright and the Early Audubon Movement. Organization \& Environment 15: 458-465. 
Glenn, Ian. 2009. Levaillant's Bird Books and the Origin of a Genre. AlterNation 16: $91-101$.

Gray, George Robert. 1840. A List of the Genera of Birds: With Their Synonyms an Indication of the Typical Species of Each Genus compiled from Various Sources. London: Richard and John E. Taylor.

Gunn, Mary Davidson, and Leslie Edward Wostall Codd. 1981. Botanical Exploration of Southern Africa. Cape Town: A. A. Balkema.

Gurney, John Henry F.Z.S. 1868. Notes on Mr. Layard's Birds of South Africa. Ibis 10: 135-164.

Habermas, Rebekka. 2016. Skandal in Togo: Ein Kapitel Deutscher Kolonialherrschaft. Frankfurt a.M.: S. Fischer Verlag.

Hammel, Tanja. 2016. Mary Barber's Expedition Journal: An Experimental Space to Voice Social Concerns. In Expedition as Experiments: Practising Observation and Documentation, ed. Marianne Klemun and Ulrike Spring, 121-140. Basingstoke/New York: Palgrave Macmillan.

Hilton-Barber, Brett, and Lee R. Berger. 2004. Field Guide to the Cradle of Humankind: Sterkfontein, Swartkrans, Kromdraai and Environs World Heritage Site. Cape Town: Struik Publishers.

Hockey, P.A.R., W.R.J. Dean, and P.G. Ryan. 2005. Roberts - Birds of Southern Africa. 7th ed. Cape Town: Trustees of the John Voelcker Bird Book Fund.

Hooker, Joseph D. 1847. On the Vegetation of the Galapagos Archipelago, as Compared with That of Some Other Tropical Islands and of the Continent of America. Transactions of the Linnean Society of London 20: 235-262.

- 1866a. Abstract of Dr. Hooker's Lecture on Insular Floras. In The British Association for the Advancement of Science, Nottingham meeting, August 1866. Report of the papers, discussions, and general proceedings, ed. William Tindal Robertson. Nottingham/London: Thomas Forman, Robert Hadrwicke.

- 1866b. Considérations sur les flores insulaires. Annales des Sciences Naturelles Botanique 5th ser. 6: 267-299.

- 1867a. "Insular Floras" [Read 27 August 1866]. Gardeners' Chronicle, 6-7, 27, 50-51, 75-76.

- 1867b. On Insular Floras: A Lecture. Journal of Botany 5: 23-31.

Hornaday, William Temple. 1913. Our Vanishing Wildlife: Its Extermination and Preservation. New York: C. Scribner's sons.

Huigen, Siegfried. 2009. Knowledge and Colonialism: Eighteenth-century Travellers in South Africa. Leiden/Boston: Brill.

Irmscher, Christoph. 1999. John James Audubon: Writings and Drawings. New York: Library of America.

Jacobs, Nancy J. 2016. Birders of Africa: History of a Network. New Haven/ London: Yale University Press.

Lalu, Premesh. 2009. The Deaths of Hintsa: Postapartheid South Africa and the Shape of Recurring Pasts. Cape Town: HSRC Press. 
Layard, Edgar Leopold. 1867. The Birds of South Africa: A Descriptive Catalogue of All the Known Species Occurring South of the 28th Parallel of South Latitude. Cape Town/London: Juta/Longman, Green \& Co..

- 1869. VI. Further Notes on South-African Ornithology. Ibis 11: 68-79.

Legassick, Martin. 2010. The Struggle for the Eastern Cape 1800-1854: Subjugation and the Roots of South African Democracy, Democracy in Africa Series. Johannesburg: KMM Review Publishing Company.

Levaillant, François. 1790a. Voyage de M. Le Vaillant das L'intérieur de l'Afrique par le Cap de Bonne Espérance, dans les Années 1783, 84 et 85. 2 vols. Paris: Leroy. - 1790b. Travels into the Interior Parts of Africa, by Way of the Cape of Good Hope; in the Years 1780, 1781 82, 83, 84, and 85. 2 vols. London: G. G. and J. Robinson.

- 1795. Second Voyage dans l'Intérieur de l'Afrique, par le Cap de BonneEspérance, dans les Années 1783, 84 et 85. 3 vols. Paris: H. J. Jansen et Comp.

. 1796. New Travels into the Interior Parts of Africa, by Way of the Cape of Good Hope, in the Years 1783, 84 and 85. 3 vols. London: G. G. and J. Robinson. J. J. Fuchs.

- 1799b. Histoire Naturelle des Oiseaux d'Afrique. Vol. 2. 6 vols. Paris: J. J. Fuchs.

- 1802. Histoire Naturelle des Oiseaux d'Afrique. Vol. 3. 6 vols. Paris: J. J. Fuchs.

- 1805. Histoire Naturelle des Oiseaux d'Afrique. Vol. 5. 6 vols. Paris: Delachaussée.

- 1806. Histoire Naturelle des Oiseaux d'Afrique. Vol. 5. Paris: Delachaussée.

- 1808. Histoire Naturelle des Oiseaux d'Afrique. Vol. 6. 6 vols. Paris: Delachaussée.

Lichtenstein, Henry. 1812. Travels in Southern Africa in the Years 1803, 1804, 1805, and 1806. Trans. Anne Plumptre. London: Henry Colburn.

Lotka, Alfred J. 1910. Contribution to the Theory of Periodic Reaction. Journal of Physical Chemistry 14: 271-274.

- 1920. Analytical Note on Certain Rhythmic Reactions in Organic Systems. Proceedings of the National Academy of Sciences of the United States of America 6: 410-415.

- 1925. Elements of Physical Biology. Baltimore: Williams and Wilkins Company.

Lubbock, John. 1877a. On Ants. The Spectator, 10-11.

- 1877b. On the Habits of Ants. Popular Science Monthly 11: 39-58.

- 1880. On the Habits of Ants. Nature 22: 184-185.

Mavor, William. 1823. Classical English Poetry for the Use of Schools and Young Persons in General. London: Longman, Hurst, Rees, Orme and Brown.

McCalman, Iain. 2010. Darwin's Armada: How Four Voyagers to Australasia Won the Battle for Evolution and Changed the World. Sydney: Penguin Books. 
McCormick, John S. 1992. The Global Environmental Movement Reclaiming Paradise. Belhaven/London: Indiana University Press.

Mda, Zakes. 2000. The Heart of Redness. Oxford: Oxford University Press.

Merchant, Carolyn. 1984. Women of the Progressive Conservation Movement: 1900-1916. Environmental Review 8: 57-85.

- 2016. Spare the Birds! George Bird Grinnell and the First Audubon Society. New Haven/London: Yale University Press.

Merriam, Florence Augusta. 1890. Birds Through an Opera-Glass. Boston: Houghton Miffli.

Merton, Robert K. 1963. Resistance to the Systematic Study of Multiple Discoveries in Science. European Journal of Sociology 4 (2): 237-282.

- 1973. The Sociology of Science: Theoretical and Empirical Investigations. Chicago: The University of Chicago Press.

Mitford-Barberton, Ivan. 1934. The Barbers of the Peak. A History of the Barber, Atherstone, and Bowker Families. Oxford: Oxford University Press.

Mostert, Noël. 1992. Frontiers: The Epic of South Africa's Creation and the Tragedy of the Xhosa People. London: Pimlico.

Müller-Wille, Staffan. 2005. Walnuts in Hudson Bay, Coral Reefs in Gotland: The Colonialism of Linnaean Botany. In Colonial Botany: Science, Commerce and Politics in the Early Modern World, ed. Londa Schiebinger and Claudia Swan, 34-48. Philadelphia: University of Pennsylvania Press.

Ormerod, Eleanor A. 1889. Icerya purchasi. In Notes and Descriptions of a Few Injurious Farm and Fruit Insects of South Africa, ed. Eleanor A. Ormerod and Oliver E. Janson, 69-98. London: Simpkin, Marshall \& Co.

Partridge, Linda Dugan. 1996. By the Book: Audubon and the Tradition of Ornithological Illustration. The Huntington Library Quarterly 59: 269-301.

Patchett, Merle. 2011. Murderous Millinery. Fashioning Feathers. https://fashioningfeathers.info/murderous-millinery (4 October 2016).

Peires, Jeff B. 1975. The Rise of the 'Right-Hand House' in the History and Historiography of the Xhosa. History in Africa 2: 113-125.

- 1979. Ngqika c. 1779-1829. In Black Leaders in Southern African History. African Historical Biographies, ed. Christopher Saunders, 15-30. London/Nairobi/Lusaka/Ibadan: Heinemann.

- 1981. The House of Phalo: A History of the Xhosa People in the Days of Their Independence. Johannesburg: Ravan Press.

—. 1989. The Dead Will Arise: Nongqawuse and the Great Xhosa Cattle Killing Movement of 1856-1857. London: Currey.

Raj, Kapil. 2007. Relocating Modern Science: Circulation and the Construction of Knowledge in South Asia and Europe, 1650-1900. New York: Palgrave Macmillan.

Rassool, Ciraj. 2006. Beyond the Cult of 'Salvation' and 'Remarkable Equality': A New Paradigm for the Bleek-Lloyd Collection. Kronos 32: 244-251. 
Rookmaaker, L.C. (Kees). 1989. The Zoological Exploration of Southern Africa 1650-1790. Rotterdam/Brookfield: A. A. Balkema.

Rookmaaker, L.C. (Kees), Peter J. Mundy, Ian E. Glenn, and Emma C. Spary. 2004. François Levaillant and the Birds of Africa. Johannesburg: Brenthurst Press.

Saxena, Jaya. 2015. How Early Feminists Helped Revolutionize Birding. Atlas Obscura, November 24.

Schiebinger, Londa. 2007. Chapter 4: Naming and Knowing: The Global Politics of Eighteenth-Century Botanical Nomenclatures. In Making Knowledge in Early Modern Europe: Practices, Objects, and Texts, 1400-1800, ed. Pamela H. Smith and Benjamin Schmidt, 90-105. Chicago/London: The University of Chicago Press.

Schonland, Selmar. 1904. Biography of the Late Mrs F.W. Barber, and a List of Her Paintings in the Albany Museum. Records of the Albany Museum 1: 95-108.

Siegfried, Roy. 2016. Levaillant's Legacy: A History of South African Ornithology. Noordhoek: Print Matters.

Sivasundaram, Sujit. 2013. Islanded: Britain, Sri Lanka, and the Bounds of an Indian Ocean Colony. Chicago: The University of Chicago Press.

Skotnes, Pippa, ed. 2007. Claim to the Country: The Archive of Lucy Lloyd and Wilhelm Bleek. Johannesburg/Cape Town/Athens: Jacana/Ohio University Press.

Smith, Jonathan. 2006. Picturing Sexual Selection: Gender and Evolution of Ornithological Illustration in Charles Darwin's Descent of Man. In Figuring It Out: Science, Gender, and Visual Culture, ed. Ann B. Shteir and Bernard V. Lightman, 85-109. Lebanon: Dartmouth College Press.

Sparrman, Andres. 1776. A Voyage to the Cape of Good Hope, Towards the Antarctic Polar Circle, and round the World: but chiefly into the country of the Hottentots and Caffres, from the Year 1772 to 1776. Vol. 2. London: G.G. J. and J. Robinson.

- 1777. An Account of a Journey into Africa from the Cape of Good-Hope, and a Description of a new Species of Cuckow. Philosophical Transactions of the Royal Society of London 67: 38-47.

Spinage, Clive A. 2012. African Ecology-Benchmarks and Historical Perspectives. Heidelberg/Dordrecht/London/New York: Springer.

Stapleton, Timothy J. 1993. The Memory of Maqoma: An Assessment of Jingqi Oral Tradition in Ciskei and Transkei. History in Africa 20: 321-335.

- 1994. Maqoma: Xhosa Resistance to Colonial Advance. Johannesburg: Jonathan Ball.

- ed. 2016. Encyclopedia of African Colonial Conflicts. 2 vols. Santa Barbara: ABC-Clio LLC.

Sundevall, Carl Jakob. 1865. Les Oiseaux d'Afrique de Levaillant. Revue et Magasin de Zoologie, pure et appliquée 2nd series, 17-18. 
The Aborigines Protection Society. 1837. Report of the Parliamentary Select Committee on Aboriginal Tribes, (British Settlements), Reprinted with Comments by the Aborigines Protection Society. London: William Ball.

Thomas, Daniel, Ron Radford, and Leigh Astbury. 1988. Creating Australia: 200 Years of Art 1788-1988. Sydney: International Cultural Corporation of Australia.

T. R. [Trimen, Roland]. 1862. On Some New Species of South African Butterflies, Collected in British Kaffraria By W. S. M. D’Urban Esq., During 1860-1861. Transactions of the Entomological Society of London 3: 398-406.

- 1864. Descriptions of Some New Species of Butterflies Found in Southern Africa. Transactions of the Entomological Society of London 3: 175-180.

- 1866. Rhopalocera Africae Australis. Vol. 2. London/Cape Town: Trübner \& Co./W. F. Mathew.

1875. Wilhelm H.I. Bleek. Cape Monthly Magazine 11, 167-169.

- 1887a. South-African Butterflies: A Monograph of the Extra-Tropical Species, Nymphalidae. Vol. 1. London: Trübner \& Co.

- 1887b. South-African Butterflies: A Monograph of the Extra-Tropical Species, Erycinidae and Lycaenidae. Vol. 2. London: Trübner \& Co.

- 1889. South-African Butterflies: A Monograph of the Extra-Tropical Species, Papilionidae and Hesperidae. Vol. 3. London: Trübner \& Co.

Trouillot, Michel-Rolph. 1995. Silencing the Past: Power and the Production of History. Boston: Beacon Press.

Volterra, Vito. 1926. Variazioni e Fluttuazioni del Numero di Individui in Specie Animali Conviventi. Memorie dell'Academia Regia Nazionale dei Lincei Roma 2: 31-113.

Wallace, Robert. 1896. Farming Industries of the Cape Colony. London: P. S. King and Son.

Walters, Michael. 2003. A Concise History of Ornithology: The Lives and Works of Its Founding Figures. London: Christopher Helm.

Watson, R.L. 2012. Slave Emancipation and Racial Attitudes in NineteenthCentury South Africa. Cambridge: Cambridge University Press.

Wells, Julia C. 2012. The Return of Makhanda: Exploring the Legend. Scottsville: University of KwaZulu-Natal Press PY.

White, Steven. 2013. British Colonialism, Australian Nationalism and the Law: Hierarchies of Wild Animal Protection. Monash University Law Review 39: $452-472$. 
Open Access This chapter is licensed under the terms of the Creative Commons Attribution 4.0 International License (http://creativecommons.org/licenses/ by $/ 4.0 /$ ), which permits use, sharing, adaptation, distribution and reproduction in any medium or format, as long as you give appropriate credit to the original author(s) and the source, provide a link to the Creative Commons licence and indicate if changes were made.

The images or other third party material in this chapter are included in the chapter's Creative Commons licence, unless indicated otherwise in a credit line to the material. If material is not included in the chapter's Creative Commons licence and your intended use is not permitted by statutory regulation or exceeds the permitted use, you will need to obtain permission directly from the copyright holder.

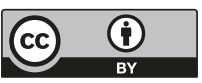

